\title{
Constructing a Scale for Development of Economic Values among Gifted High School Students at Al-Ahsa Region
}

\author{
Rommel Mahmoud Alali \\ The National Research Center for Giftedness and Creativity, King Faisal University, Al-Ahsa, Saudi Arabia
}

Received November 17, 2020; Revised January 5, 2021; Accepted January 28, 2021

\begin{abstract}
Cite This Paper in the following Citation Styles
(a): [1] Rommel Mahmoud Alali, Constructing a Scale for Development of Economic Values among Gifted High School Students at Al-Ahsa Region," Universal Journal of Educational Research, Vol. 9, No. 2, pp. 329 - 341, 2021. DOI: 10.13189/ujer.2021.090209.
\end{abstract}

(b): Rommel Mahmoud Alali (2021). Constructing a Scale for Development of Economic Values among Gifted High School Students at Al-Ahsa Region. Universal Journal of Educational Research, 9(2), 329 - 341. DOI: 10.13189/ujer.2021.090209.

Copyright $C 2021$ by authors, all rights reserved. Authors agree that this article remains permanently open access under the terms of the Creative Commons Attribution License 4.0 International License

\begin{abstract}
Values have an important role in guiding the thinking and behavior of the individual. The society is suffering from many economic problems, as it is living in a difficult situation. Since students are part of society, so they have an important role in building, progressing and developing their society. Therefore, this study aims to construct a scale of economic values for gifted high school students at Al-Ahsa region. The developed scale covered four concepts including the value of rationalization of consumption (R), the value of work (W), value of respect public property ownership $(\mathrm{O})$ and value of respect workers and professionals and their appreciation (A). The validity and reliability of the 55 items were tested using Raasch Model analysis. The study sample consisted of (310) respondents. The findings showed that there were statistically significant differences in the scale based on gender in favor of female. While there were no statistically significant differences based on academic branch, academic level and interaction between variables demographic of the study. Finally, the study recommended that adoption of the economic values scale in the region for gifted high school students from educators and interested in the educational process. In addition, the study promotes the economic values of students and implies economic concepts and values in all curricula.
\end{abstract}

Keywords Economic Values, Gifted High School Students, Rasch Model, Psychometric Properties

\section{Introduction}

The issue of values is one of the fundamental issues affecting human relations. Educational psychologists were interested in the study of values. Values have a significant role in regulating the behavior of individuals, and their judgments and attitudes. Values are directly related to human behavior, which define and guide it in the areas of life. It also plays an essential role in the formation of individual personality and actions, cohesion, stability, and progress of society $[35,37]$. Values play a role in the occurrence of social and economic change. Because it is a social phenomenon that obstructs change or help in the occurrence to fit with the social needs in society including the negative or positive values. According to David McClelland, economic development requires changing values, traditional norms in society to new values and standards that push the process of economic development $[34,30]$. Values are an important aspect in the study of organizational behavior, its form to understand attitudes and motivations, affect our perception, incentive force and organization of behavior and specifically for objectives and policies [6, 23]. Technical development requires a change in values, so the value has specific importance in the life of the individual 
and society. Value forms culture and is considered the path of growth and progress [20]. E. Spranger classified the values into six categories: theoretical, economic, aesthetic, social, religious and political values [32].

Therefore, the Kingdom of Saudi Arabia attaches great importance to students through the provision of the enrichment programs offered by the General Directorate of Gifted Education in the Ministry of Education. The school represents the best environment for caring for gifted students, which represents their psychological stability and communication with their colleagues and with school and their sense of belonging. The earlier provision of care to gifted students gives them more chances to develop their abilities and talents. The preparation of the Gifted Education Program in school has been implemented in six educational departments with five teachers and one supervisor. They have been trained on gifted care strategies within the school. In addition, adopting the idea of qualifying national cadres that able the provision of specialized educational care for the students' diverse talents in order to work as permanent members of public education schools [10].

Most individuals are born with several creative abilities and varied talents. It can grow and develop in different age stages if it is cared for and are given attention to. Therefore, it is necessary to make young people able to face life in the era of excellence and creativity. The gifted are the cornerstone of civilization and rich wealth in the fields of development and progress of the nation. Therefore, they must be given the necessary care and put in the appropriate environment to reveal their talents and potential energies $[14,7]$. The nature of the gifted appears and sometimes disappears for many reasons, social or psychological. Therefore, it is necessary to follow up on this development and change to enhance the strengths and attempts to address weaknesses to keep this talent glowing. Many creative qualities feature gifted students despite the unique characteristics of each gifted, such as curiosity, fluency, flexibility, and originality. Besides, high ability of imagination, manipulation of ideas, love of discovery, high sensitivity to beauty and strength of opinions and beliefs $[15,16]$.

The study of creative teaching practices is an important issue in higher education $[10,21]$. Creative teaching is considered an educational activity that carried out by the faculty member using three steps: planning, implementation and evaluation in order to make a qualitative change in the learners' behavior. The faculty member performs a range of creative methods during his/her teaching to achieve the desired goals. Creative methods are based on making changes in social, educational and socialization processes through educational programs based on the productive thought development, provoking creative thinking, training on fertile imagination and creative problem solving [14].
Creative teaching practices are those teaching methods and patterns of behavior practiced and preferred by the faculty member, and distinguish him/ her from others [1, 12]. Teaching practices should focus on creative and innovation $[8,9]$.

Values have an important role in guiding the thinking and behavior of the individual. Although values have relative stability, it changes from generation to others by the entry or disappearance of new values. The technological progress in communication have become students' values are continually changing and renewed. The contemporary society is also suffering from many economic problems, as it is living in a difficult situation. Since students are part of society, so they have an important role in building, progressing and developing their society. Therefore, it is necessary to develop a scale of economic values to keep up with change and renewal in these values. Economic problems are part of our lives. High unemployment, competition in global markets, free trade and inflation. Besides, there are many social, political and environmental problems that have significant economic impacts $[30,5,43]$.

Values are inseparable from education. The interrelations between them make education affect the individual economically and in many aspects, whether it is a distinct personality with economic interests, or an individual has economic relations with others, or being a worker involved in the economic production of society. For the individual to keep up with economic changes, he must base his relations on the right economic values. Therefore, the interest of instilling economic values among students is important, which is no less important than the knowledge that is provided to them. The development of these values will guide them to the right and economical disposition, and to deal with things in an oriented and civilized way, to be a lover of effective and productive work, committed to his ethics. Dealing with modern resources requires all saving and rationalization of consumption, planning and development, respect for each worker, and appreciation of the value of his work. The focus on the consolidation of economic values in the individual makes it possible for their effects to appear in his behavior in the future. Teaching the primary principles of economic values for the individual is an attempt to gain the right economic habits that will affect it later [29, 25].

The individual adapts to behavioral traits useful to him and other people, such as self-reliance, and the desire to do the work with acceptance and relaxation. This leads to the formation of a good man who is able to interact with society, which achieves satisfaction and happiness for him and others. Economic values have a great impact on the individual by increasing self-confidence; this leads to higher production rates, the community progress in the renaissance and industrial, agricultural and commercial civilization. Economic values motivate young people to 
develop their intellectual curricula that will reflect success or failure in the economy, hence the need to strengthen those values. The secondary school stage is important, namely adulthood and adolescence, which is one of the most dangerous stages facing parents and educators. Therefore, he must be truthful and have a good and strong personality $[30,2]$. So this study aimed at constructing and developing a scale of economic values for gifted high school students in the Al-Ahsa region. Furthermore, the research questions in this article are: What are the psychometric properties of economic value scale constructed to determine if it is sufficiently valid and reliable as a predictor of economic value scale? In addition, is there any significant difference in the economic value among gifted high school students in the Al-Ahsa region due to gender, academic Branch and educational level?

\section{Literature Review}

The study by Al - Ruwaili [39] aimed to identify the role of secondary school in the development of economic values among high school students as perceived by students, by identifying the role of the components of the school community (Teacher, school administration curriculum - school activity) in developing the economic values of high school students from their point of view. The results showed that the role of the teacher got the highest average followed by the role of management and then the role of the curriculum and finally the role of school activity. Al-Arfaj [3] conducted a study aimed to identify the contribution of the school administration in the secondary stage in building three main values among the students. These values represent the culture of successful firms which are innovative, good service, and affiliation. The results showed that students are opposed to the assumption that there is no culture of successful firms in both schools. The results also indicated that they oppose the assumption that none of the three values, however, they estimated the existence of these values at low levels. The study by Stuer \& Mezaros [36] aimed at the importance of economic education in schools. They found that economic illiteracy in the United States of America increased during the years from (1992 to 2000). The income of an individual has increased by (47\%) but its expenditure increased by $61 \%$. During these eight years, the personal saving rate has dropped from about $6 \%$ to $0 \%$. Half of Americans live within their daily income, and $(50 \%)$ of all adults did not start saving. Young people should be prepared to control their economic affairs smartly. Many strategies can be used to teach economic values in schools.

Racko [33] conducted a study aimed to explore the formation values among students at the Stockholm School of Economics to prepare economists and professionals for emerging economic institutions. The study also analyzed the impact of social and academic contexts on students' economic values. The study concluded that social and academic context factors influenced the formation of students 'economic values, and that social and academic students' experiences had an impact on the process of changing their economic values. The study by Suiter and Meszaros [40] aimed to teach savings and investment in primary and middle schools by addressing the strategies that can be used to teach economic values in schools. The study concluded that many strategies can be used to teach economic values in schools through school activities, role-playing, active learning, learning through groups and others. Al-Shammari [13] conducted a study aimed to identify the extent to which student activities contributed to the development of economic values among high school students. Also the detection of obstacles that limit the activities of student role in the development of economic values. The study concluded that student activities play a role in the development of some economic values, such as respect for handwork, rationalization of consumption, productivity and take responsibility. Many constraints limit student activities in developing economic values, such as the negative impact of some students on their colleagues, Poor use of life situations that have a role in the development of those values.

Al-Rabaani Al-Makhlafi [12] conducted a study aimed to detect the level of economic awareness among students of social studies at Sultan Qaboos University. The results showed a weak level of economic awareness among students and their lack of economic information. It also recommended the need to develop students' economic information in the field of investment and banking transactions, enhance their attitudes towards investment and benefit from the information provided by the media and communication, and work to develop their information on how to make better use of their money. The study by Al-Doosry [5] aimed to recognize the reality of the secondary school's contribution to the development of the economic awareness of their students. It also recognizes the means it can take in enhancing its contribution to the development of economic awareness of their students. The results showed that the approval of the sample of the study in a medium degree on the reality of the contribution of the secondary school in developing the economic awareness of their students. It also contributes to the development of respect for time and love of work among students as economic values. In a study by Mittal [30], the values of male and female secondary school students with their socio-economic status were examined and compared. The results showed that the existence of the average level of values among all high school students. While female secondary school student's preferred economic values on others. In addition, social and economic status had a significant impact on the 
religious, social, family and health values among students. Abu Zeid \& Al Zuod [1] conducted a study aimed at identifying the most and least important values of secondary school students in Amman Governorate as perceived by the students themselves. The results showed that the economic values ranked penultimate according to importance. In addition, there were no statistically significant differences due to gender, variables of class, family income, and education area.

\section{Rasch Model Analysis (RM)}

One of the most important models of the item response theory is Rasch model RM, because it achieves the objective property and independence in psychological and educational measurement. It is one of the simplest models because it includes one parameter related to item difficulty, assumes the equal discrimination of all items, provides the opportunity to delete inappropriate individuals and items which in turn provides the validity of the scale. Furthermore, it provides the reliability of the scale because it achieves the independence property. The use of Rasch model in the construction of a scale indicates the availability of an objective in the measurement of ability variable, which means verifying the validity and reliability of the estimates of both individuals' capabilities and items scale $[27,24]$. RM helps to estimate the probability of an individual answering to item correctly, in terms of the individual's ability, and the difficulty coefficient of the item, regardless of the sample size and number of items.

\section{Methodology}

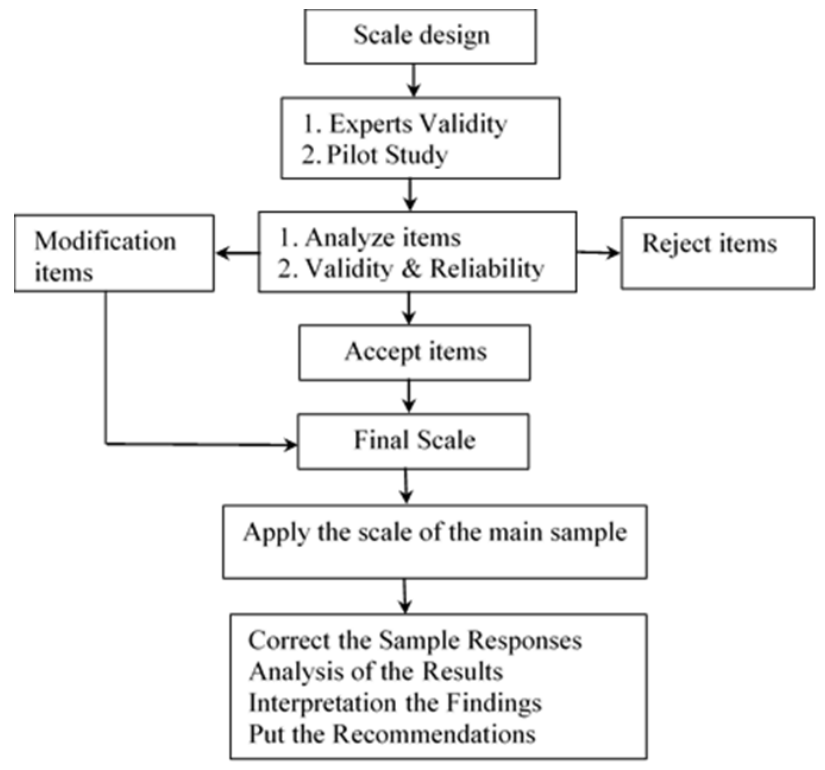

Figure 1. Procedures for Scale

This study used a quantitative descriptive survey approach. The population consisted of all gifted high school students at Al-Ahsa region during the academic year 2019/2020. Al-Ahsa region has been randomly selected from Saudi Arabia Governorates. The sample of this study consisted of 500 gifted high school students. To achieve the objectives of the study and answer the research questions, economic values of gifted students' scale was developed. The scale is used to measure the economic values of gifted students. It consisted of four dimensions namely the value of rationalization of consumption (R), the value of work (W), value of respect public property ownership $(\mathrm{O})$ and value of respect workers and professionals and their appreciation (A).

\section{The Development of Scale Steps}

Defining the objective of the scale, which is to measure the economic values of gifted high school students. Determining dimensions of economic values by reviewing literature review. The scale consisted of four dimensions as mentioned previously. Developing of items scale by reviewing the previous studies. The final copy of the scale consisted of 55 items.

\subsection{Verifying the Validity and Reliability of the Scale}

The validity of the scale was verified. The scale items were examined by 9 experts from the University of King Faisal. Based on their opinions, the researcher modified and reformulated some scale items, it also some items were omitted. To ensure the validity and reliability, the scale was piloted with some 30 gifted high school students, and the responses and feedback obtained were used in modifying the final scale. The data were analyzed using SPSS version 24. In addition, it analyzed and evaluated according to Rasch model using Winsteps software version 3.68.2.

The next step is to find the validity of the instruments by determining the discriminant coefficient (Corrected item- total Correlation) using SPSS. The items that have discriminant coefficient of less than .20 were omitted. After that, the construct validity was verified using internal consistency validity method and Rasch model analysis. Students' responses were used in the calculation of matrix correlation coefficients between the subscales and the total score as shown in Table 1.

Table 1 represents matrix correlation coefficients between the mean of subscales (AV.R, AV.W, AV.O and AV.A) and the mean of total score (AV.TOT). It also shows that the values of correlation coefficients are relatively high, this indicates that all involved in the measurement of a single concept of economic values, emphasizes the correlation of sub-scores with the total score. This is an indicator of the scale validity [41].

Cronbach Alpha: The reliability coefficient for the items scale is equal to 0.74 . This value indicates that the scale has a good degree of reliability. 
Table 1. Correlations Matrix of Development of Economic Values Scale

\begin{tabular}{|c|c|c|c|c|c|c|}
\hline & & AV.TOT & AV.R & AV.W & AV.o & AV.A \\
\hline \multirow{2}{*}{ AV.TOT } & Pearson Correlation & 1 & $.540 * *$ & $.835^{* *}$ & $.774 * *$ & $.844 * *$ \\
\hline & Sig. (2-tailed) & & .000 & .000 & .000 & .000 \\
\hline \multirow{2}{*}{ AV.R } & Pearson Correlation & $.540^{* *}$ & 1 & .173 & .064 & .215 \\
\hline & Sig. (2-tailed) & .000 & & .000 & .000 & .000 \\
\hline \multirow{2}{*}{ AV.W } & Pearson Correlation & $.835^{* *}$ & .173 & 1 & $.515^{* *}$ & $.712 * *$ \\
\hline & Sig. (2-tailed) & .000 & .000 & & .000 & .000 \\
\hline \multirow{2}{*}{ AV.O } & Pearson Correlation & $.774 * *$ & .064 & $.515^{* *}$ & 1 & $.614 * *$ \\
\hline & Sig. (2-tailed) & .000 & .000 & .000 & & .001 \\
\hline \multirow{2}{*}{ AV.A } & Pearson Correlation & $.844 * *$ & .215 & $.712 * *$ & $.614 * *$ & 1 \\
\hline & Sig. (2-tailed) & .000 & .000 & .000 & .001 & \\
\hline
\end{tabular}

Table 2. Item Fit Analysis for Economic Values Scale

\begin{tabular}{|c|c|c|c|c|c|c|c|}
\hline \multirow{3}{*}{$\begin{array}{c}\text { Items } \\
\mathrm{R} 2 \\
\end{array}$} & \multirow{3}{*}{$\begin{array}{c}\text { measure } \\
-.34 \\
\end{array}$} & \multirow{3}{*}{$\begin{array}{c}\begin{array}{c}\text { Model } \\
\text { S.E }\end{array} \\
0.29 \\
\end{array}$} & \multicolumn{2}{|c|}{ Infit } & \multicolumn{2}{|c|}{ Outfit } & \multirow{3}{*}{$\begin{array}{c}\begin{array}{c}\text { Pt-measure } \\
\text { CORR }\end{array} \\
0.21\end{array}$} \\
\hline & & & MNSQ & ZSTD & MNSQ & ZSTD & \\
\hline & & & 1.24 & 0.8 & 1.46 & 1.5 & \\
\hline R9 & -.16 & 0.29 & 1.24 & 0.7 & 1.16 & 0.7 & 0.23 \\
\hline O5 & .22 & 0.2 & 1.28 & 1.4 & 1.29 & 1.4 & 0.24 \\
\hline W5 & -.27 & 0.22 & 1.22 & 1 & 1.19 & 0.9 & 0.24 \\
\hline W4 & .18 & 0.19 & 1.29 & 1.3 & 1.29 & 1.3 & 0.26 \\
\hline R3 & .43 & 0.22 & 1.21 & 1 & 1.21 & 1 & 0.29 \\
\hline $\mathrm{O} 10$ & -.16 & 0.29 & 1.13 & 0.6 & 1.16 & 0.7 & 0.31 \\
\hline $\mathrm{R} 1$ & .04 & 0.27 & 1.14 & 0.6 & 1.19 & 0.7 & 0.31 \\
\hline $\mathrm{R} 8$ & -1.08 & 0.55 & 1.04 & 0.2 & 1.09 & 0.4 & 0.37 \\
\hline A2 & -.48 & 0.36 & 1.06 & 0.3 & 1.17 & 0.7 & 0.38 \\
\hline R11 & -1.19 & 0.2 & 1.16 & 0.8 & 1.16 & 0.8 & 0.39 \\
\hline R6 & -.76 & 27 & 1.08 & 0.4 & 1.15 & 0.7 & 0.39 \\
\hline $\mathrm{O} 13$ & .37 & 0.2 & 1.12 & 0.5 & 1.14 & 0.6 & 0.42 \\
\hline R4 & -.53 & 0.19 & 1.12 & 0.6 & 1.16 & 0.7 & 0.42 \\
\hline A11 & .66 & 0.23 & 1.06 & 0.3 & 1.2 & 0.6 & 0.44 \\
\hline R7 & -.09 & 0.21 & 1.07 & 0.4 & 1.06 & 0.4 & 0.46 \\
\hline W3 & -.25 & 0.25 & 1.04 & 0.3 & 1.06 & 0.3 & 0.47 \\
\hline A1 & .37 & 0.62 & 0.99 & 0.1 & 0.93 & 0 & 0.51 \\
\hline W6 & -.28 & 0.19 & 1.08 & 0.4 & 1.09 & 0.4 & 0.51 \\
\hline $\mathrm{O} 2$ & -.37 & 0.18 & 1.1 & 0.5 & 1.09 & 0.5 & 0.53 \\
\hline $\mathrm{R} 12$ & .42 & 0.35 & 0.98 & 0 & 0.96 & -0.1 & 0.53 \\
\hline $\mathrm{O} 11$ & -.19 & 0.23 & 1.02 & 0.2 & 1.07 & 0.3 & 0.54 \\
\hline O6 & .08 & 0.27 & 1.02 & 0.2 & 1 & 0.1 & 0.55 \\
\hline A6 & .77 & 0.38 & 0.97 & 0.1 & 0.91 & -0.1 & 0.57 \\
\hline $\mathrm{O} 14$ & .16 & 0.16 & 1.06 & 0.3 & 1.88 & 1.3 & 0.57 \\
\hline A5 & -.38 & 0.32 & 0.98 & 0 & 1.04 & 0.2 & 0.59 \\
\hline $\mathrm{R} 10$ & .51 & 0.16 & 1.09 & 0.5 & 1.11 & 0.6 & 0.59 \\
\hline $\mathrm{O} 3$ & .01 & 0.19 & 1.05 & 0.3 & 1.06 & 0.3 & 0.61 \\
\hline R5 & 1.05 & 0.23 & 1 & 0.1 & 1.01 & 0.1 & 0.61 \\
\hline O4 & .17 & 0.29 & 0.96 & 0.1 & 0.88 & -0.1 & 0.64 \\
\hline W8 & .23 & 0.21 & 1.02 & 0.2 & 0.95 & -0.1 & 0.65 \\
\hline O9 & -.18 & 0.18 & 1.05 & 0.3 & 0.9 & -0.1 & 0.65 \\
\hline
\end{tabular}


Table 2 Continuous

\begin{tabular}{|c|c|c|c|c|c|c|c|}
\hline A14 & -.48 & 0.14 & 1.08 & 0.4 & 1.06 & 0.3 & 0.69 \\
\hline W13 & .04 & 0.21 & 0.95 & 0.1 & 0.83 & -0.3 & 0.69 \\
\hline $\mathrm{O} 7$ & -.27 & 0.17 & 0.97 & 0 & 1.01 & 1 & 0.69 \\
\hline O1 & -.71 & 0.34 & 0.93 & 0 & 0.75 & -0.4 & 0.70 \\
\hline W9 & -.21 & 0.23 & 0.93 & -0.2 & 0.94 & -0.2 & 0.71 \\
\hline A8 & -.63 & 0.17 & 0.95 & -0.2 & 0.95 & -0.1 & 0.73 \\
\hline $\mathrm{A} 10$ & .29 & 0.29 & 0.94 & -0.3 & 0.85 & -0.5 & 0.74 \\
\hline A9 & -.73 & 0.16 & 0.91 & -0.2 & 0.94 & -0.2 & 0.74 \\
\hline W15 & -.09 & 0.32 & 0.89 & 0.1 & 0.46 & -0.4 & 0.76 \\
\hline O8 & -.37 & 0.16 & 0.94 & -0.2 & 0.92 & -0.3 & 0.77 \\
\hline $\mathrm{A} 13$ & -.09 & 0.29 & 0.9 & -0.4 & 0.84 & -0.6 & 0.77 \\
\hline $\mathrm{O} 12$ & .51 & 19 & 0.9 & -0.3 & 0.88 & -0.4 & 0.79 \\
\hline A4 & .01 & 0.23 & 0.85 & -0.4 & 0.74 & -0.8 & 0.79 \\
\hline W11 & 1.05 & 0.15 & 0.87 & -0.6 & 0.86 & -0.6 & 0.81 \\
\hline W2 & .17 & 0.35 & 0.88 & -0.5 & 0.86 & -0.5 & 0.81 \\
\hline A3 & .23 & 0.55 & 0.9 & -0.2 & 0.76 & -0.5 & 0.82 \\
\hline W10 & -.18 & 0.17 & 0.81 & -0.8 & 0.81 & -0.7 & 0.83 \\
\hline $\mathrm{A} 12$ & -.48 & 0.17 & 0.79 & -1 & 0.8 & -0.9 & 0.83 \\
\hline W14 & .04 & 0.16 & 0.77 & -1.1 & 0.77 & -1.1 & 0.83 \\
\hline W12 & -.27 & 0.23 & 0.79 & -0.6 & 0.67 & -1 & 0.84 \\
\hline W7 & .03 & 0.28 & 0.79 & 0.1 & 0.77 & -1.1 & 0.85 \\
\hline $\mathrm{A} 7$ & .20 & 0.18 & 0.72 & -1 & 0.68 & -1.1 & 0.85 \\
\hline W1 & -.57 & 0.36 & 0.8 & -0.9 & 0.81 & -0.9 & 0.87 \\
\hline
\end{tabular}

Table 3. Calibration Scaling Analysis of Economic Values Scale

\begin{tabular}{|c|c|c|c|c|c|c|c|}
\hline $\begin{array}{c}\text { Category } \\
\text { Lable }\end{array}$ & Score & $\begin{array}{c}\text { Observed } \\
\text { Count \% }\end{array}$ & $\begin{array}{c}\text { Observed } \\
\text { Average }\end{array}$ & $\begin{array}{c}\text { Infit } \\
\text { MNSQ }\end{array}$ & $\begin{array}{c}\text { Outfit } \\
\text { MNSQ }\end{array}$ & $\begin{array}{c}\text { Structure } \\
\text { Calibration }\end{array}$ & $\begin{array}{c}\text { Category } \\
\text { Measure }\end{array}$ \\
\hline 2 & 2 & $\begin{array}{c}2 \\
4\end{array}$ & -.32 & .68 & .60 & None & $(-2.49)$ \\
\hline 3 & 3 & $\begin{array}{c}7 \\
20\end{array}$ & .43 & .83 & .48 & -1.16 & -.86 \\
\hline 4 & 4 & $\begin{array}{c}14 \\
56\end{array}$ & .57 & .81 & .66 & -.49 & .75 \\
\hline 5 & 5 & $\begin{array}{c}7 \\
20\end{array}$ & .96 & .63 & .88 & 1.65 & $(2.87)$ \\
\hline
\end{tabular}

\subsection{Validity and Reliability Using Rasch Model}

To ensure the validity using Rasch model it should be verifying: first; the item-fit Statistics, and the values of MNSQ for infit lies between .4-1.5 to be appropriate. Second, item polarity analysis (Point Measure Correlation), the acceptable value for PTMEA lies between .2-1.0. Third, calibration scaling analysis. Finally, the dimensionality is also used to verify both content and construct validity $[26,19,42,17,38]$. Table 2 showed that the Item Polarity and Item Fit Analysis for Economic Values Scale.

Table 2 shows that the values of MNSQ for infit ranged between .72 and 1.29. Moreover, the values of PTMEA ranged between .21 and .87 . According to Rasch model, the above values are appropriate and acceptable for construct validity. Table 3 and figure 2 below showed a summary of the category structure on a scale gradation and size structure of the intersection. It also showed the schedules for grading scale calibration analysis of the scale.

Table 3 shows the most frequent answer is the scale of participants ranking 4 which $14(56 \%)$ the scales 3 and 7 of $7(20 \%)$. The last grading scale was scale 2 of $2(4 \%)$. The column of observed averages shows the pattern of respondents moves from negative to positive (-.32 to .96). This indicates normal pattern based on Rasch model. 


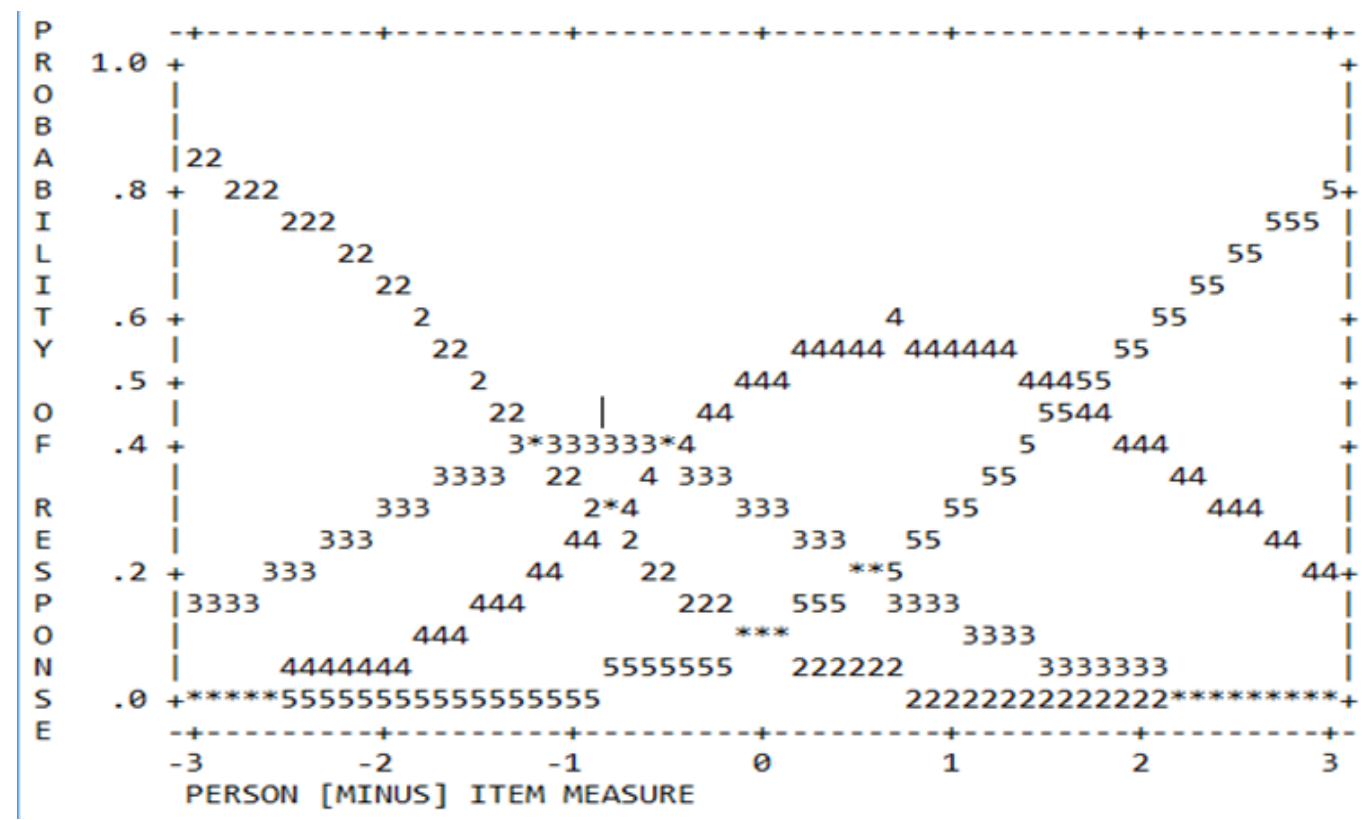

Figure 2. The Summary of the category structure on a scale gradation

Table 4. Item Dimensionality of Economic Values Scale

\begin{tabular}{|c|c|c|c|}
\hline & \multicolumn{2}{|c|}{ Empirical } & Modeled \\
\hline Total raw variance in observations & 74.9 & $100 \%$ & $100 \%$ \\
\hline $\begin{array}{c}\text { Raw variance explained by } \\
\text { measures }\end{array}$ & 19.9 & $26.6 \%$ & $26.9 \%$ \\
\hline $\begin{array}{c}\text { Raw variance explained by } \\
\text { persons }\end{array}$ & 4.4 & $5.8 \%$ & $5.9 \%$ \\
\hline Raw Variance explained by items & 15.6 & $20.8 \%$ & $21.0 \%$ \\
\hline Raw unexplained variance (total) & 55.0 & $73.4 \%$ & $100.0 \%$ \\
\hline Unexplained var.in 1st contrast & 7.6 & $10.2 \%$ & $13.9 \%$ \\
\hline Unexplained var.in 2nd contrast & 6.4 & $8.6 \%$ & $11.7 \%$ \\
\hline $\begin{array}{c}\text { Unexplained var.in 3rd contrast } \\
\text { Unexplained variance in 4th } \\
\text { contrast }\end{array}$ & 5.4 & $7.2 \%$ & $9.8 \%$ \\
\hline $\begin{array}{c}\text { Unexplained variance in 5th } \\
\text { contrast }\end{array}$ & 4.2 & $5.6 \%$ & $7.6 \%$ \\
\hline
\end{tabular}

Tables 4 show the raw variance explained by measures is $74.9 \%$, it is more than $40 \%$. The unexplained variance in 1 st contrast is $7.6 \%$, which is less than 15 . Hence, dimensionality data result was appropriate to Rasch model.

To ensure the reliability using Rasch model it should be verifying the person and item reliability. The criteria of reliability should be $50 \%$ and more. Furthermore, item and person separation values should be more than 2 to be acceptable [31, 42]. Tables 5 and 6 below show that the person separation and reliability and item separation and reliability for economic values scale. The person and item reliability are greater than .5 , which are .74 and .76 respectively. Furthermore, the person and item separation are greater than 2, which are 2.17 and 2.13 respectively. Based on Rasch model these reliability values indicate that the scale has good degree of reliability. 
Table 5. Person Separation and Reliability for Economic Values Scale

\begin{tabular}{|c|c|c|c|c|c|c|c|c|}
\hline & \multirow{2}{*}{$\begin{array}{l}\text { Raw } \\
\text { Score }\end{array}$} & \multirow{2}{*}{ Count } & \multirow{2}{*}{ Measure } & \multirow{2}{*}{ Error } & \multicolumn{2}{|c|}{ Infit } & \multicolumn{2}{|c|}{ Outfit } \\
\hline & & & & & MNSQ & ZSTD & MNSQ & ZSTD \\
\hline Mean & 214.0 & 55.0 & .61 & .15 & .98 & -0.1 & 1.33 & -.6 \\
\hline S.D. & 13.8 & .0 & .29 & .01 & .29 & 1.5 & .26 & 1.2 \\
\hline Real Rmse & .16 & & & & & & & \\
\hline ADJ.SD & .25 & & & & & & & \\
\hline Separation & 2.17 & & & & & & & \\
\hline $\begin{array}{c}\text { Person } \\
\text { Reliability }\end{array}$ & .76 & & & & & & & \\
\hline
\end{tabular}

Table 6. Item Separation and Reliability for Economic Values Scale

\begin{tabular}{|c|c|c|c|c|c|c|c|c|}
\hline & \multirow{2}{*}{$\begin{array}{l}\text { Raw } \\
\text { Score }\end{array}$} & \multirow{2}{*}{ Count } & \multirow{2}{*}{ Measure } & \multirow{2}{*}{ Error } & \multicolumn{2}{|c|}{ Infit } & \multicolumn{2}{|c|}{ Outfit } \\
\hline & & & & & MNSQ & ZSTD & MNSQ & ZSTD \\
\hline Mean & 97.3 & 25.0 & -1.43 & .25 & 1 & .1 & .85 & .1 \\
\hline S.D. & 18.8 & .0 & .56 & .10 & .13 & .6 & .22 & .7 \\
\hline Real Rmse & .44 & & & & & & & \\
\hline ADJ.SD & .49 & & & & & & & \\
\hline Separation & 2.13 & & & & & & & \\
\hline $\begin{array}{c}\text { Person } \\
\text { Reliability }\end{array}$ & .74 & & & & & & & \\
\hline
\end{tabular}

\section{Findings}

To answer the first question: What are the psychometric properties of economic value scale constructed to determine if it is sufficiently valid and reliable as a predictor of economic value scale?

The validity and reliability of the study scale were verified in different ways as previously shown. The constructs of scale were developed and tested using Rasch Model analysis. The psychometric properties of scale developed to determine if they are sufficiently valid and reliable as a predictor of scale. This indicates that the scale has high psychometric properties, which enables it to be used effectively and efficiently.

To answer the second question: is there any significant difference in the economic value among gifted high school students in the Al-Ahsa region due to gender, academic branch and educational level?

To answer this question, the means value, standard deviations, T- Test, one-way analysis of variance and multivariate analysis of variance are used.

Table 7 shows that the mean value response of females in all dimensions of the scale and in the whole of the scale (avTOT) 4.1435 are higher than that of males 3.7917.
Table 7. Comparison of the Economic Values of Gifted High School Students in relation to their Gender

\begin{tabular}{|c|c|c|c|c|}
\hline \multicolumn{2}{|c|}{} & $\mathbf{N}$ & Mean & Std. Deviation \\
\hline \multirow{4}{*}{ avR } & Male & 165 & 3.7867 & .46507 \\
\cline { 2 - 5 } & Female & 145 & 4.1913 & .47013 \\
\cline { 2 - 5 } & Total & 310 & 3.9623 & .50766 \\
\hline \multirow{4}{*}{ avW } & Male & 165 & 3.5733 & .39572 \\
\cline { 2 - 5 } & Female & 145 & 3.8826 & .51496 \\
\cline { 2 - 5 } & Total & 310 & 3.7075 & .47570 \\
\hline & Male & 165 & 3.8367 & .33455 \\
\cline { 2 - 5 } & Female & 145 & 4.1478 & .47149 \\
\hline \multirow{3}{*}{ avA } & Total & 310 & 3.9717 & .42766 \\
\cline { 2 - 5 } & Male & 165 & 3.9783 & .42331 \\
\cline { 2 - 5 } & Female & 145 & 4.3630 & .47131 \\
\hline \multirow{3}{*}{ avTOT } & Total & 310 & 4.1453 & .48310 \\
\cline { 2 - 5 } & Male & 165 & 3.7917 & .25490 \\
\cline { 2 - 5 } & Female & 145 & 4.1435 & .33457 \\
\hline
\end{tabular}


Table 8. Comparison of the Economic Values of Gifted High School Students in Relation to their Academic Branch

\begin{tabular}{|c|c|c|c|c|}
\hline \multicolumn{2}{|c|}{} & N & Mean & Std. Deviation \\
\hline \multirow{4}{*}{ avR } & Scientific & 277 & 4.0025 & .49266 \\
\cline { 2 - 5 } & literary & 33 & 3.8727 & .57024 \\
\cline { 2 - 5 } & Total & 277 & 3.7466 & .46105 \\
\hline \multirow{4}{*}{ avW } & Scientific & 33 & 3.5515 & .57343 \\
\cline { 2 - 5 } & literary & 277 & 4.0058 & .43041 \\
\cline { 2 - 5 } & Total & 33 & 3.8242 & .44723 \\
\hline \multirow{4}{*}{ avO } & Scientific & 277 & 4.1823 & .46990 \\
\cline { 2 - 5 } & literary & 33 & 4.0121 & .56886 \\
\cline { 2 - 5 } & Total & 277 & 3.9798 & .35246 \\
\hline \multirow{4}{*}{ avA } & Scientific & 33 & 3.8212 & .32089 \\
\cline { 2 - 5 } & literary & 277 & 4.0025 & .49266 \\
\cline { 2 - 5 } & Total & 33 & 3.8727 & .57024 \\
\hline \multirow{4}{*}{ avTOT } & Scientific & 277 & 3.7466 & .46105 \\
\cline { 2 - 5 } & literary & 33 & 3.5515 & .57343 \\
\cline { 2 - 5 } & Total & 277 & 4.0058 & .43041 \\
\hline
\end{tabular}

Table 8 shows that the mean values response of scientific branch students in three dimensions (first, third and fourth) and in whole of the scale (avTOT) 4.0025, $4.1823,3.8212$ and 3.7466 respectively are higher than that of literary branch students. While the mean values response of literary branch students in the second dimension, which is the value of work is higher than that of scientific branch students. Table 9 shows the results of $\mathrm{T}$ - Test for differences between means according to gender and Academic branch.

Table 9 showed that the value of $(t=.667)$ for whole dimensions indicated that there were statistically significant differences for the differences among the means. In other word, there were statistically significant differences among the responses of the sample on the economic values scale according to gender. The value of $(\mathrm{t}=.333)$ for whole dimensions indicated that there was no statistically significant difference for the differences between the means, where the significant level is greater than (0.05). In other word, there were no statistically significant differences among the responses of the sample on the economic values scale according to academic branch.

Table 9. The results of T-Test for differences between means according to gender and Academic branch

\begin{tabular}{|c|c|c|c|c|c|c|c|}
\hline \multicolumn{3}{|c|}{ Variables and Dimensions } & No. & Mean & S. D. & T value & Sig. \\
\hline \multirow{10}{*}{ Gender } & \multirow{2}{*}{ avR } & Male & 165 & 3.7867 & .46507 & \multirow{2}{*}{.856} & \multirow{2}{*}{0.009} \\
\hline & & Female & 145 & 4.1913 & .47013 & & \\
\hline & \multirow{2}{*}{ avW } & Male & 165 & 3.5733 & .39572 & \multirow{2}{*}{.560} & \multirow{2}{*}{0.97} \\
\hline & & Female & 145 & 3.8826 & .51496 & & \\
\hline & \multirow{2}{*}{$\mathrm{avO}$} & Male & 165 & 3.8367 & .33455 & \multirow{2}{*}{1.947} & \multirow{2}{*}{0.089} \\
\hline & & Female & 145 & 4.1478 & .47149 & & \\
\hline & \multirow{2}{*}{ avA } & Male & 165 & 3.9783 & .42331 & \multirow{2}{*}{1.947} & \multirow{2}{*}{0.089} \\
\hline & & Female & 145 & 4.3630 & .47131 & & \\
\hline & \multirow{2}{*}{ Whole dimensions } & Male & 165 & 3.7917 & .25490 & \multirow{2}{*}{.667} & \multirow{2}{*}{0.039} \\
\hline & & Female & 145 & 4.1435 & .33457 & & \\
\hline \multirow{10}{*}{$\begin{array}{l}\text { Academic } \\
\text { branch }\end{array}$} & \multirow{2}{*}{ avR } & Scientific & 277 & 4.23 & .706 & \multirow{2}{*}{.401} & \multirow{2}{*}{0.072} \\
\hline & & Literary & 33 & 4.02 & .576 & & \\
\hline & \multirow{2}{*}{ avW } & Scientific & 277 & 4.22 & .659 & \multirow{2}{*}{.005} & \multirow{2}{*}{0.019} \\
\hline & & Literary & 33 & 3.94 & .607 & & \\
\hline & \multirow{2}{*}{$\mathrm{avO}$} & Scientific & 277 & 4.21 & .755 & \multirow{2}{*}{.112} & \multirow{2}{*}{0.092} \\
\hline & & Literary & 33 & 4.01 & .602 & & \\
\hline & \multirow{2}{*}{ avA } & Scientific & 277 & 4.24 & .684 & \multirow{2}{*}{.112} & \multirow{2}{*}{0.171} \\
\hline & & Literary & 33 & 4.07 & .573 & & \\
\hline & \multirow{2}{*}{ Whole dimensions } & Scientific & 277 & 4.22 & .682 & \multirow{2}{*}{.333} & \multirow{2}{*}{0.061} \\
\hline & & Literary & 33 & 4.01 & .574 & & \\
\hline
\end{tabular}


Table 10 shows that the mean values response of students in all dimensions of the scale from high to low in relation to their educational level are the second year of the secondary stage (4.0381), the first year of the secondary stage (3.9662) and the third year of the secondary stage (3.9000) respectively. Table 11 below shows the results of one-way analysis of variance for the economic values scale according to Educational Level.

Table 11 showed that there were no statistically significant differences in all dimensions of economic values scale based on educational level, where the significant level was greater than 0.05 . In general, there were no statistically significant differences in economic values scale as a total based on educational level.

Table 10. Comparison of the Economic Values of Gifted High School Students in relation to their Educational Level

\begin{tabular}{|c|c|c|c|c|}
\hline & & $\mathbf{N}$ & Mean & Std. Deviation \\
\hline \multirow{4}{*}{ avR } & First year of secondary & 134 & 3.9873 & .59943 \\
\hline & Second year of secondary & 83 & 4.0795 & .36014 \\
\hline & Third year of secondary & 93 & 3.9097 & .44479 \\
\hline & Total & 310 & 3.9887 & .50207 \\
\hline \multirow{4}{*}{ avW } & First year of secondary & 134 & 3.7261 & .51866 \\
\hline & Second year of secondary & 83 & 3.7940 & .39551 \\
\hline & Third year of secondary & 93 & 3.6645 & .47746 \\
\hline & Total & 310 & 3.7258 & .47702 \\
\hline \multirow{4}{*}{$\mathrm{avO}$} & First year of secondary & 134 & 3.9716 & .43522 \\
\hline & Second year of secondary & 83 & 4.0952 & .41228 \\
\hline & Third year of secondary & 93 & 3.9108 & .44022 \\
\hline & Total & 310 & 3.9865 & .43512 \\
\hline \multirow{4}{*}{ avA } & First year of secondary & 134 & 4.1796 & .45789 \\
\hline & Second year of secondary & 83 & 4.1835 & .50439 \\
\hline & Third year of secondary & 93 & 4.1194 & .50136 \\
\hline & Total & 310 & 4.1642 & .48322 \\
\hline \multirow{4}{*}{ avTOT } & First year of secondary & 134 & 3.9662 & .36903 \\
\hline & Second year of secondary & 83 & 4.0381 & .29831 \\
\hline & Third year of secondary & 93 & 3.9000 & .36445 \\
\hline & Total & 310 & 3.9629 & .35217 \\
\hline
\end{tabular}

Table 11. The Results of Analysis of Variance of Differences among the Means of Responses of the Sample on Economic Values Based on Educational Level

\begin{tabular}{|c|c|c|c|c|c|c|c|}
\hline \multicolumn{3}{|c|}{ variance source } & Sum of Squares & df & $\begin{array}{c}\text { Mean } \\
\text { Square }\end{array}$ & $\mathbf{F}$ & Sig. \\
\hline \multirow{17}{*}{$\begin{array}{c}\text { Academic } \\
\text { Rank }\end{array}$} & \multirow{3}{*}{ avR } & Between Groups & 15.783 & 2 & 7.892 & \multirow{3}{*}{24.073} & \multirow{3}{*}{.346} \\
\hline & & Within Groups & 52.452 & 147 & .357 & & \\
\hline & & Total & 68.235 & 149 & & & \\
\hline & \multirow{3}{*}{ avW } & Between Groups & 9.097 & 2 & 4.548 & \multirow{3}{*}{19.655} & \multirow{3}{*}{.127} \\
\hline & & Within Groups & 54.956 & 147 & .374 & & \\
\hline & & Total & 64.053 & 149 & & & \\
\hline & \multirow{3}{*}{$\mathrm{avO}$} & Between Groups & 11.825 & 2 & 5.912 & \multirow{3}{*}{72.426} & \multirow{3}{*}{.218} \\
\hline & & Within Groups & 65.312 & 147 & .444 & & \\
\hline & & Total & 77.137 & 149 & & & \\
\hline & \multirow{3}{*}{ avA } & Between Groups & 13.401 & 2 & 6.701 & \multirow{3}{*}{72.426} & \multirow{3}{*}{.218} \\
\hline & & Within Groups & 50.954 & 147 & .347 & & \\
\hline & & Total & 64.355 & 149 & & & \\
\hline & \multirow{5}{*}{$\begin{array}{c}\text { Whole } \\
\text { dimensions }\end{array}$} & Between Groups & 12.362 & 2 & 6.181 & \multirow{5}{*}{51.208} & \multirow{5}{*}{.326} \\
\hline & & Within Groups & 52.342 & 147 & .356 & & \\
\hline & & Total & 64.704 & 149 & & & \\
\hline & & Within Groups & 63.938 & 147 & .435 & & \\
\hline & & Total & 64.704 & 149 & & & \\
\hline
\end{tabular}


Table 12. The Results of Multivariate Analysis of Variance in Economic Values Based on the Gender, Academic Branch and Educational Level

\begin{tabular}{|c|c|c|c|c|c|c|}
\hline Source & Dependent Variable & $\begin{array}{c}\text { Type III Sum of } \\
\text { Squares }\end{array}$ & df & Mean Square & $\mathbf{F}$ & Sig. \\
\hline \multirow{5}{*}{ Gender } & avR & 2.439 & 1 & 2.439 & 11.683 & .001 \\
\hline & avW & .949 & 1 & .949 & 4.885 & .028 \\
\hline & $\mathrm{avO}$ & .521 & 1 & .521 & 3.143 & .077 \\
\hline & avA & 2.035 & 1 & 2.035 & 11.943 & .001 \\
\hline & avTOT & 1.401 & 1 & 1.401 & 15.939 & .000 \\
\hline \multirow{5}{*}{ Branch } & avR & .002 & 1 & .002 & .008 & .927 \\
\hline & avW & .090 & 1 & .090 & .461 & .498 \\
\hline & $\mathrm{avO}$ & .444 & 1 & .444 & 2.677 & .103 \\
\hline & avA & .078 & 1 & .078 & .460 & .498 \\
\hline & avTOT & .092 & 1 & .092 & 1.051 & .306 \\
\hline \multirow{5}{*}{ Level } & avR & .199 & 2 & .100 & .477 & .621 \\
\hline & avW & .489 & 2 & .245 & 1.260 & .285 \\
\hline & avO & .451 & 2 & .225 & 1.360 & .258 \\
\hline & avA & .054 & 2 & .027 & .157 & .855 \\
\hline & avTOT & .142 & 2 & .071 & .805 & .448 \\
\hline \multirow{5}{*}{ Gender * Branch } & avR & .031 & 1 & .031 & .149 & .699 \\
\hline & avW & .341 & 1 & .341 & 1.758 & .186 \\
\hline & avO & .551 & 1 & .551 & 3.328 & .069 \\
\hline & avA & .754 & 1 & .754 & 4.426 & .036 \\
\hline & avTOT & .333 & 1 & .333 & 3.790 & .053 \\
\hline \multirow{5}{*}{ Gender * Level } & avR & .781 & 2 & .391 & 1.871 & .156 \\
\hline & avW & .654 & 2 & .327 & 1.683 & .188 \\
\hline & $\mathrm{avO}$ & .193 & 2 & .096 & .581 & .560 \\
\hline & avA & 2.856 & 2 & 1.428 & 8.379 & .000 \\
\hline & avTOT & .222 & 2 & .111 & 1.260 & .285 \\
\hline \multirow{5}{*}{ Branch * Level } & avR & .039 & 2 & .019 & .093 & .911 \\
\hline & avW & .427 & 2 & .213 & 1.098 & .335 \\
\hline & $\mathrm{avO}$ & .125 & 2 & .062 & .377 & .687 \\
\hline & avA & .438 & 2 & .219 & 1.284 & .278 \\
\hline & avTOT & .138 & 2 & .069 & .785 & .457 \\
\hline \multirow{5}{*}{ Gender * Branch * Level } & avR & .378 & 2 & .189 & .906 & .405 \\
\hline & avW & 1.442 & 2 & .721 & 3.711 & .026 \\
\hline & avO & .296 & 2 & .148 & .893 & .410 \\
\hline & avA & 1.182 & 2 & .591 & 3.468 & .032 \\
\hline & avTOT & .357 & 2 & .178 & 2.029 & .133 \\
\hline
\end{tabular}

Table 12 shows that there are statistically significant differences in all dimensions of the scale based on gender in favor of female. While there are no statistically significant differences in all dimensions of the scale based on academic branch, and educational level. Based on interaction between gender and branch, interaction between gender and level, interaction between academic branch and educational level and interaction between gender, academic branch and educational level there are no statically significant differences in all dimensions of the scale.

\section{Discussion of the Results}

The results showed that there are statistically significant differences in all dimensions of the scale based on gender in favor of female, because females are trying to prove themselves in all fields, especially economic. The females are no less efficient than males [8, 22, 21, 30]. 
Females are more able than males to perceive hints and details, speed in processing information, organizing ideas, ability to discover weaknesses, differences in situation and lack of information. This helped females to present. The requirements of life have led to the promotion of encouraging economic values for female work. Females have an ambition to keep pace with technological progress. It is not surprising that the results point in favor of females, at a time when Saudi Arabia is witnessing an educational and social renaissance, with increasing attention to women. This result inconsistent with some studies that showed there are no statistically significant differences in values scale based on gender for many reasons, such as similarity in social, economic and cultural conditions, maturity factor in understanding of life and they lived in the same zone $[43,1,5,18]$.

As for academic branch, the results were logical, there are no statistically significant differences in all dimensions of the scale based on academic branch. Because the sample study from gifted students and most of them have equal motivation to face life problems, similarity in social, economic and cultural conditions [5]. This result inconsistent with some studies that showed there are statistically significant differences in values scale based on academic branch in favor of scientific [22, $21]$ and in favor of literary $[43,18]$.

Regarding of academic level, the results showed that there are no statistically significant differences in all dimensions of the scale. Because all students are gifted, mature and conscious, where they are able to face any hard economic conditions and to promote encouraging economic values $[8,44]$.

Inconsistency of the study results with other studies is due to varying time between this study and previous studies. Furthermore, different environments and population of study.

\section{Recommendations}

1. The study recommends the adoption of the economic values scale for gifted high school students from educators and interested in the educational process.

2. Implying economic concepts and values in all curricula, especially the secondary level.

3. Encourage and promote the economic values of students, especially males, to face the challenges and difficult economic conditions.

4. Conducting training programs and workshops related to economic concepts, principles and values for secondary school students periodically.

\section{REFERENCES}

[1] Abu Zeid, M. \& Al Zuod, S. (2007). Educational values among secondary school students in Amman governorate as perceived by the students themselves. Dirasat: Educational Sciences, 34(3). 735-765.

[2] AlAgha, S. \& Nassar, A. (2008). The Role of the Palestinian Media in Supporting the Values among the Adolescents in Gaza Governorates. Journal of the Islamic University, 16(1), 633-682.

[3] Al-Arfaj, A. (2002). The contribution of the school management in Hofuf to the development of some values of work for students. Scientific Journal of Human and Administrative Sciences King Faisal University, 3(1).

[4] Al-Balkhi, M. (1991). The growth of the values of students in the preparatory stage and its relation to the teaching of history [Unpublished master's thesis]. Damascus University.

[5] Al-Doosry R. Z. (2016). High School Contribution in Developing Students' Economic Awareness as Perceived by Teachers. Taibah University Journal for Educational Science. 11(3), 465-483.

[6] Al-Harbi, A. (2010). The Role of science teacher in developing third grade high school students scientific values In KSA [Unpublished doctoral dissertation]. Um-Alqura University.

[7] Al-Ghamdi, H. (2007). Obstacles facing talented students in basic education in Saudi Arabia. A study presented to the Regional Scientific Conference of Talent. King Abdulaziz $\&$ his Companions Foundation for Giftedness and Creativity.

[8] Al Jawarneh, A. (2001). Educational Values Practiced amongst Students of the Faculty of Sharia at Yarmouk University [Unpublished master's thesis]. Yarmouk University, Jordan.

[9] Aljughaiman, A. (2008). Gifted Education Program in Public Education Schools. Ministry of Education, Saudi Arabia.

[10] Al-Laqani, A. \& Aljammal, A. (1999). Dictionary of educational terms defined in the curriculum and Methods of Teaching. Cairo World of Books.

[11] Al-Rabaani, A. \& Al-Makhlafi, M. (2011). Sultan Qaboos University Social Studies Student Teachers' Level of Economic Awareness. Journal of Educational \& Psychological Sciences, 12(4), 285-311.

[12] Al-Shammari A. (2018). The role of student activities in the development of some economic values among high school students in Hail from the perspective of students. Journal of Fayoum University of Science Educational and Psychological, 9(5), 1-18.

[13] Al-Sharif, M. (2015). The program of the gifted in the schools of general education in the Kingdom of Saudi Arabia between the reality and the hope of an educational perspective. Second International Conference of Talents and Gifted. United Arab Emirates University.

[14] Al-Sorour, N. (2010). Introduction to the education of the privileged and talented. Amman Dar al- Fikr.

[15] Al-Zu'bi, A. (2014). Creative self-efficacy among gifted students and their teachers in Jordan. Journal of Jordan in of educational sciences, Yarmouk University, 10(4), 475-488. 
[16] Aziz, A. A. (2010). Rasch model fundamentals: scale construct and measurement structure. Kuala Lumpur: Perpustakaan Negara Malaysia.

[17] Baker, M. \& Ameen, A. (2011). The Dominant Values of Universities students in the light of some variables. Journal of Educational and Psychological, 28, 96-151.

[18] Bond, T. (2015). Applying the Rasch model: Fundamental measurement in the human sciences. Routledge. https://doi.org/10.4324/9781315814698

[19] Bouatit, S. (2017). Economic and Political Values and their Relationship to the Professional Compatibility of Faculty Members. Psychological and Educational Studies, 18, 77-91.

[20] El-Gohary, S. (2005). The prevailing values of Benghazi University students and their relationship to the type of academic branch and academic [Unpublished master's thesis]. Benghazi University.

[21] Hamid, F. (2006). The prevailing values and their relation to psychosocial Compatibility among students of 7 October University in Misrata [Unpublished master's thesis]. University of Misrata.

[22] Indira, K. (2009). Effect of Value Pattern on Achievement in Physics of Secondary School Pupils. GCTE Journal of Research and Extension in Education, 4(2), 41- 46.

[23] Kim, B., \& Hong, S. (2004). A psychometric revision of the Asian Values Scale using the Rasch model. Measurement and Evaluation in Counseling and Development, 37(1), 15-27. https://doi.org/10.1037/t07402-000

[24] Lihmoud, H. K. (2010). The role of the kindergarten teacher in establishing the economic values at Kindergarten children aged (5-6) years [Unpublished master's thesis]. Damascus University.

[25] Linacre, J. M. (2009). A User's guide to Winsteps-ministep: Rasch-model computer programs. Program Manual 3.68. 0. Chicago, IL.

[26] McCamey, R. (2015). A primer on the one-parameter Rasch model. American Journal of Economics and Business Administration, 6(4), 159-163.

[27] Michael, Amataneus (2001). The value preferences of students at Damascus University in the light of a number of variables. Damascus University Journal of Educational Sciences, 17(3), 9-53.

[28] Melhem, I. (2000). Learn the child in the family and school. Damascus Dar Alaeddin Publications.

[29] Mittal, A. (2016). A study of values of secondary school students in relation to their socio- economic status and modernization. Learning Community: An International
Journal of Educational and Social Development, 7(3), 203.

[30] Mofreh, S. M., Gafar, M. A., Omar, A. H., Latif, A., \& Hamid, D. H. (2017). Validation of Instrument on Teaching Practices Among Lecturers at Community Colleges, Yemen. Sains Humanika, 9(3-2). https://doi.org/10.11113/sh.v9n32.1274

[31] Oles, P. K., \& Hermans, H. J. (2010). Allport - Vernon Study of Values. The Corsini encyclopedia of psychology, 1-2. https://doi.org/10.1002/9780470479216.corpsy0038

[32] Racko, G. (2008). A Study of Value Change among Economics Students at the Stockholm School of Economics in Riga [Unpublished master's thesis]. University of Cambridge.

[33] Rosenberg, D. (2000). A Manager's Guide to Hiring the Best Person for Every Job. John Wiley \& Sons, Inc.

[34] Santrock, J. W. (2017). Educational psychology. McGraw-Hill Education.

[35] Suiter, M., \& Meszaros, B. (2005). Teaching about saving and investing in the elementary and middle school grades. Social Education, 69(2), 92-95.

[36] Wahid, Ahmed (2001). Social Psychology. Amman: Dar Al-Masirah for Printing and Publishing.

[37] Wu, M., \& Adams, R. (2007). Applying the Rasch model to psycho-social measurement: A practical approach. Melbourne: Educational Measurement Solutions.

[38] AL-Ruwaili, S. (2007). The Development of Economic Values in Secondary School Students in the City of Arar from Their Perspective [Unpublished master's thesis]. King Saud University.

[39] Meszaros, B. \& Suiter, M., (2005). Teaching about saving and investing in the elementary and middle school grades. Social Education, 69(2), 92-95.

[40] AlAli, R. A., Ghafar, M. N. and Mofreh, S (2016). Social perception of mathematics among Jordanian students in higher education. Journal of Institutional Research South East Asia, 14(1), 112-126.

[41] Fischl, C., \& Fisher, A. G. (2007). Development and Rasch analysis of the assessment of computer-related skills. Scandinavian Journal of Occupational Therapy, 14(2), 126-135.

[42] Alomary, A. (2015). The Degree of Values among the Students of Jordanian Universities. Dirasat Educational Sciences, 42(3), 1063-1086.

[43] Nasir, M. (2008). The Values claimed among students of Zarqa Private University. Damascus University Journal for Educational Sciences, 24(2), 359-397. 